Original Article

\title{
New records of the occurrence of Megaleporinus macrocephalus (Garavello \& Britski, 1988) (Characiformes, Anostomidae) from the basins of the Itapecuru and Mearim rivers in Maranhão, Northeastern Brazil
}

\author{
Novos registros da ocorrência de Megaleporinus macrocephalus (Garavello \& Britski, \\ 1988) (Characiformes, Anostomidae) nas bacias dos rios Itapecuru e Mearim no \\ Maranhão, Nordeste, Brasil
}

\author{
M. S. Almeida ${ }^{a *}$ (D), P. S. S. Moraes ${ }^{b}$ (D), M. H. S. Nascimento ${ }^{c}$ (D) J. L. O. Birindellid (D), F. M. Assega ${ }^{d}$ (D), M. C. Barros ${ }^{b}$ (D) \\ and E. C. Fraga ${ }^{a}$ (i) \\ anniversidade Estadual do Maranhão - UEMA, Departamento de Química e Biologia, Programa de Pós-Graduação em Recursos Aquáticos e \\ Pesca, São Luís, MA, Brasil \\ bUniversidade Estadual do Maranhão - UEMA, Laboratório de Genética e Biologia Molecular - GENBIMOL, Caxias, MA, Brasil \\ 'Universidade Estadual do Maranhão - UEMA, Centro de Ciências Agrárias - CCA, Programa de Mestrado em Ciência Animal - CCMA, São Luís, \\ MA, Brasil \\ dUniversidade Estadual de Londrina, Departamento de Biologia Animal e Vegetal, Londrina, PR, Brasil
}

\begin{abstract}
The "piaussu", Megaleporinus macrocephalus is an anostomatid fish species native to the basin of the Paraguay River, in the Pantanal biome of western Brazil. However, this species has now been recorded in a number of other drainages, including those of the upper Paraná, Uruguay, Jacuí, Doce, Mucuri, and Paraíba do Sulrivers. This study presents two new records of the occurrence of $M$. macrocephalus, in the basins of the Itapecuru and Mearim rivers in the state of Maranhão, in the Brazilian Northeast. The piaussu is a large-bodied fish of commercial interest that is widely raised on fish farms, and its occurrence in the Itapecuru and Mearim rivers is likely the result of individuals escaping from fish tanks when they overflow during the rainy season. Morphological analyses and sequences of the Cytochrome Oxidase Subunit I (COI) gene confirmed the taxonomic identification of the specimens as M. macrocephalus. The COI sequences were $99.66 \%$ similar to those of M. macrocephalus deposited in the BOLDSystems database. These records extend the known distribution of M. macrocephalus to the basins of the Itapecuru and Mearim rivers in the Brazilian Northeast, highlighting a new case of introduction of exotic fish species into Brazilian river basins.
\end{abstract}

Keywords: freshwater, Ichthyofauna, taxonomy, biological invasion, COI.

\begin{abstract}
Resumo
Megaleporinus macrocephalus é uma espécie de peixe anostomatídeo nativa da bacia do rio Paraguai, no bioma Pantanal do oeste do Brasil. No entanto, essa espécie já foi registrada em várias outras drenagens, incluindo as dos rios Alto Paraná, Uruguai, Jacuí, Doce, Mucuri e Paraíba do Sul. Este estudo apresenta dois novos registros da ocorrência de M. macrocephalus, nas bacias dos rios Itapecuru e Mearim, no estado do Maranhão, no nordeste brasileiro. O piaussu é um peixe de grande porte, de interesse comercial, amplamente criado em pisciculturas, e sua ocorrência nos rios Itapecuru e Mearim é provavelmente o resultado de indivíduos que escapam dos tanques quando transbordam durante a estação chuvosa. Análises morfológicas e sequências do gene da subunidade I do citocromo oxidase (COI) confirmaram a identificação taxonômica dos espécimes como M. macrocephalus. As sequências de COI foram 99,66\% semelhantes às de M. macrocephalus depositadas no banco de dados BOLDSystems. Esses registros estendem a conhecida distribuição de M. macrocephalus às bacias dos rios Itapecuru e Mearim, no nordeste brasileiro, destacando um novo caso de introdução de espécies exóticas de peixes nas bacias hidrográficas brasileiras.
\end{abstract}

Palavras-chave: água doce, Ictiofauna, taxonomia, invasão biológica, COI.

*e-mail: almeidasp101@gmail.com

Received: January 9, 2020 - Accepted: June 15, 2020

This is an Open Access article distributed under the terms of the Creative Commons Attribution License, which permits unrestricted use, distribution, and reproduction in any medium, provided the original work is properly cited. 


\section{Introduction}

The family Anostomidae is currently composed of 149 valid species, distribuided in 15 genera (Fricke et al., 2020). Species of the family are endemicthe Neotropical region, and a widely distributed from north of the Colombia to La Plata River, in Argentina (Garavello and Britski, 2003). The greatest diversity of anostomatids is found in the Amazon basin, where 91 species have been recorded to date (Dagosta and Pinna, 2019). The genus Leporinus Agassiz, 1829, is the most species-rich of Anostomidae (Burns et al., 2017).

Garavello and Britski (1988) described Leporinus macrocephalus based on 15 specimens collected in the Paraguay River basin in Brazil. The species was recently transferred to Megaleporinus, a genus described in 2017 by Ramirez et al. (2017), based on morphological, molecular, and cytogenetic data, including a unique system of ZZ/ZW sex chromosomes.

The fish of the genus Megaleporinus are relatively large in size (adult standard length typically over $35 \mathrm{~cm}$ ), and are diagnosed among anostomids by having the following combination of exclusive features: premaxilla with three unicuspid teeth; dentary with three unicuspid teeth; and body with one to four dark midlateral blotches (Ramirez et al., 2017).

Megaleporinus macrocephalus (Garavello and Britski, 1988), known in Brazil as the "piaussu", "piavuçu” or "piau-açu", is an omnivorous fish that feeds on small fruit and seeds, as well as small fish and crabs (Peruca et al., 2000; Navarro et al., 2006). M. macrocephalus is distributed in the Paraguay River in Argentina, Brazil, Bolivia and Paraguay (Garavello and Britski, 1988; Britski et al., 1999; Fricke, 2019). However, individuals escaped from fish farms have colonized a number of other South American basins, including that of the upper Paraná River (Graça and Pavanelli, 2007; Langeani et al., 2007), the Jacuí and Uruguay Rivers in the Brazilian state of Rio Grande do Sul (Bertaco et al., 2016), the Mucuri River (Gomes et al., 2015), and the Doce and Paraíba do Sul rivers (Alves et al., 2007). The piaussu is commercially important for sports fishing (Zeinad and Prado, 2012) and is widely raised on fish farms to supply markets in southern and central Brazil (Soares et al., 2000; IBGE, 2014).

The present study provides the first report of the occurrence of M. macrocephalus in northeastern Brazil, more specifically in the Itapecuru and Mearim rivers, in the state of Maranhão. The Mearim is the state's largest hydrographic basin, and plays an important role in the economy and subsistence of the region's riverside populations (Maranhão, 2011). These records are the first evidence of the occurrence of $M$. macrocephalus in the Itapecuru and Mearim Rivers, extending the limits of the known geographic distribution of the species.

\section{Material and Methods}

Specimens of $M$. macrocephalus were collected in the basins of the Itapecuru and Mearim rivers, in the state of Maranhão, Northeastern Brazil (Figure 1). The Mearim

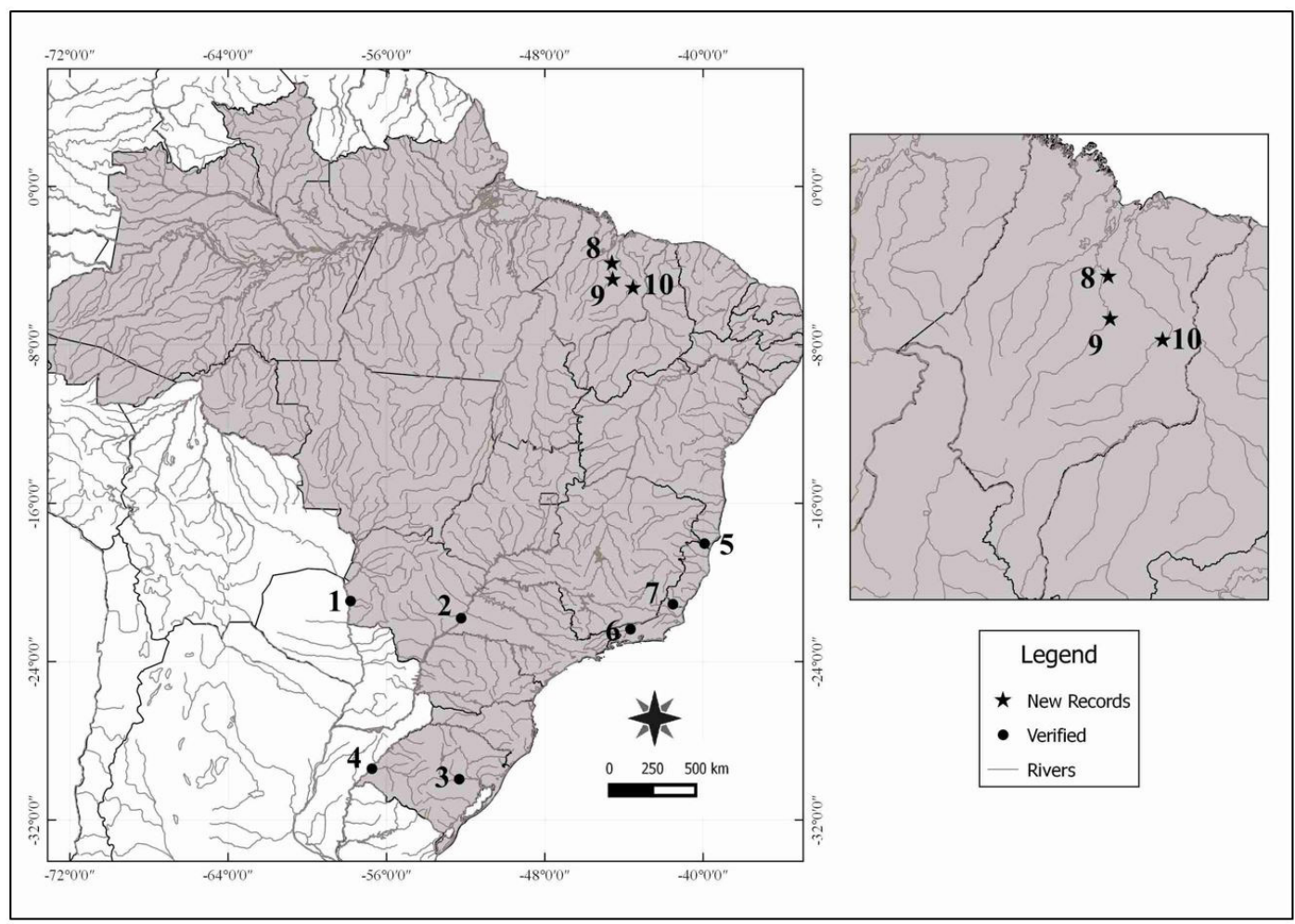

Figure 1. Geographic distribution of Megaleporinus macrocephalus in Brazil. The area of the new registrations for the Itapecuru rivers in the municipality of Pé da Serra and Mearim in the locality Laje dos Currais, in São Mateus, and in the city of Pedreiras in the Northeast Region. 
River has a total extension of $832.18 \mathrm{~km}$, and has a number of tributaries, in particular the Pindaré River, which joins the Mearim only $20 \mathrm{~km}$ from the mouth of the Grajaú River, a second important tributary of the Mearim River. The Itapecuru River is located wholly within the state of Maranhão, and has three distinct stretches - the upper river (from the source to the municipality of Colinas), the middle river (from Colinas to the municipality of Caxias), and the lower Itapecuru, from Caxias to the mouth, in São José Bay (Alcântara, 2004). The Itapecuru River, which is $852.71 \mathrm{~km}$ long, has eight major tributaries on its right margin, in particular the Pirapemas and Itapecuruzinho Rivers, and the Seco, do Ouro, Gameleira, Cachimbo, and Guariba streams (UEMA, 2016).

The specimens were collected using gill, drag, and cast nets. The voucher specimens were taken to the Laboratory of Genetics and Molecular Biology (GENBIMOL) at the Center for Higher Studies at Maranhão State University (CESC/UEMA), fixed in 10\% formalin, and conserved in $70 \%$ alcohol. The prepared specimens were sent to the Zoology Museum at the State University of Londrina (MZUEL), Paraná, Brazil, for morphological identification and cataloguing (voucher MZUEL: 15357 - Mearim river) e (voucher MZUEL: 20221 - Itapecuru river).

The collection of specimens was authorized by the Brazilian Federal Institute for the Environment and Renewable Natural Resources (IBAMA) through licence number 02012.004159/2006, and ICMBio/MMA licence 42119-2, from the Chico Mendes Institute for Biodiversity Conservation.

Measurements were taken following Britski and Garavello (1978) and Birindelli et al. (2013). Morphometric data were obtained with a digital caliper with accuracy of $0.01 \mathrm{~mm}$. Counts of scales and rays were taken according to Birindelli et al. (2013).

Samples of muscle tissue were extracted from the specimens for the genetic analyses. The total DNA was extracted using the Promega Wizard Genomic DNA purification kit, following the manufacturer's instructions. The Cytochrome Oxidase Subunit I (COI) was then amplified by Polymerase Chain Reaction, using the universal primers COI FishF1: 5" -TCAACCAACCACAAAGACATTGCCAC - 3"; and COI FishR1: 5" - TAGACTTCTGGGTGGCCAAAGAATCA - 3", as described by Ward et al. (2005). The samples were sequenced by Sanger et al. (1977) dideoxyterminal method, using a Big Dye kit in an ABI Prism ${ }^{\mathrm{TM}} 3500$ automatic sequencer (Applied Biosystems, USA). The sequences were edited and aligned in BIOEDIT 7.0 (Hall, 1999), and plotted in the BOLD Systems v4 platform (BOLD, 2020) to evaluate their similarity with existing sequences (Ratnasingham and Hebert, 2007).

\section{Results}

On the Mearim River, one M. macrocephalus specimen was collected on the lower course of the river at Laje dos Currais, in the municipality of São Mateus, during the flood season, while two specimen was obtained on the middle course of the river in the town of Pedreiras during the dry (low water) season. The M. macrocephalus specimen was collected at the locality of Pé da Serra in the municipality of Caxias during the dry season.

The four M. macrocephalus specimens (Table 1) present a characteristic coloration pattern, with a darker superior half of the body, three large black spots on each flank, and dark lines between the rows of scales (Ramirez et al., 2017). The body is robust, and the mouth terminal, with three teeth in the pre-maxillary bone and three teeth in

Table 1. Morphological data of Megaleporinus macrocephalus.

\begin{tabular}{|c|c|c|}
\hline \multirow[t]{2}{*}{ Characters } & $\begin{array}{l}\text { MZUEL } \\
20221\end{array}$ & $\begin{array}{c}\text { MZUEL } \\
15357\end{array}$ \\
\hline & Itapecuru & Mearim \\
\hline Standard Length (mm) & 387.1 & 175.2 \\
\hline \multicolumn{3}{|c|}{ Percentages of standard length } \\
\hline Predorsal distance & 41.10 & 43.83 \\
\hline $\begin{array}{l}\text { Dorsal-fin origin to adipose-fin } \\
\text { origin }\end{array}$ & 41.37 & 37.76 \\
\hline Prepelvic distance & 43.40 & 47.62 \\
\hline Body depth & 28.14 & 28.06 \\
\hline Caudal-peduncle length & 11.41 & 12.50 \\
\hline Caudal-peduncle depth & 16.93 & 15.45 \\
\hline Anal-fin lobe length & 10.59 & 10.04 \\
\hline Head length & 22.32 & 27.26 \\
\hline \multicolumn{3}{|c|}{ Percentages of head length } \\
\hline Preopercle length & 75.81 & 64.68 \\
\hline Snout length & 35.78 & 29.45 \\
\hline Head depth & 96.92 & 85.41 \\
\hline Eye diameter & 13.33 & 23.51 \\
\hline Bony interorbital & 58.88 & 54.53 \\
\hline \multicolumn{3}{|c|}{ Meristics } \\
\hline Lateral-line scales & 43 & 42 \\
\hline $\begin{array}{l}\text { Scale rows between lateral line } \\
\text { and dorsal-fin origin }\end{array}$ & 7 & 7 \\
\hline $\begin{array}{l}\text { Scale rows between lateral line } \\
\text { and anal-fin origin }\end{array}$ & 6 & 6 \\
\hline $\begin{array}{l}\text { Scale rows around caudal } \\
\text { peduncle }\end{array}$ & 16 & 16 \\
\hline Predorsal scales & 13 & 13 \\
\hline Dorsal-fin unbranched rays & 2 & 2 \\
\hline Dorsal-fin branched rays & 10 & 10 \\
\hline Pectoral-fin branched rays & 14 & 15 \\
\hline Pelvic-fin branched rays & 8 & 8 \\
\hline Anal-fin unbranched rays & 3 & 3 \\
\hline Anal-fin branched rays & 8 & 8 \\
\hline Upper caudal-fin branched rays & 9 & 9 \\
\hline Upper caudal-fin branched rays & 8 & 8 \\
\hline Teeth on left premaxilla & 3 & 3 \\
\hline Teeth on left dentary & 3 & 3 \\
\hline
\end{tabular}




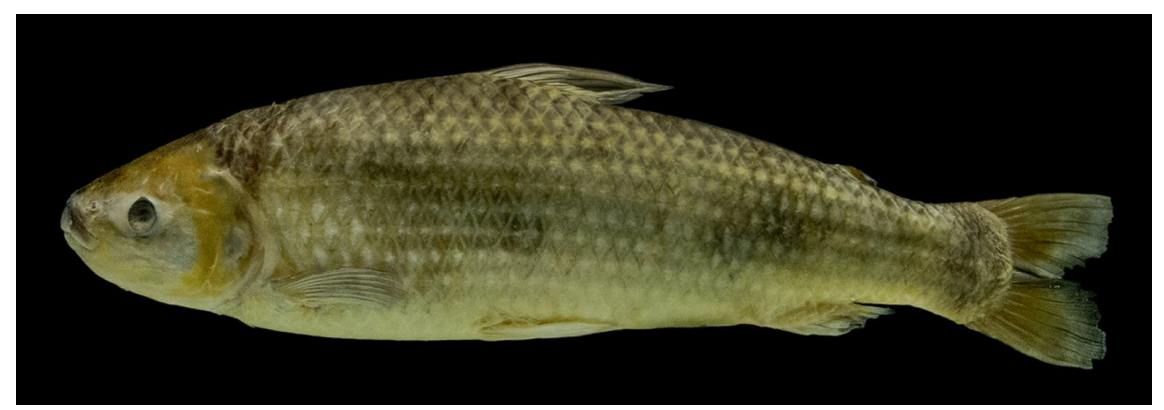

Figure 2. Megaleporinus macrocephalus, MZUEL 20221, 387.10 mm SL.

Table 2. Similarity percentage obtained by comparing the sequences of the COI gene on the BOLDSystems platform (The Barcode of Life Data System) for the M. macrocephalus species from the Itapecuru and Mearim rivers, Maranhão, Brazil, identified morphologically and which were confirmed with the molecular data.

\begin{tabular}{cccc}
\hline & \multicolumn{2}{c}{ Identificação } \\
\hline Código & N & Taxonômica & Molecular: Bold \\
\hline MEA 831 & 1 & M. macrocephalus & M. macrocephalus (99. 66\%) \\
MEA 835 & 1 & M. macrocephalus & M. macrocephalus (99. 66\%) \\
MEA 836 & 1 & M. macrocephalus & M. macrocephalus (99. 66\%) \\
LEP 158 & 1 & M. macrocephalus & M. macrocephalus (99. 66\%) \\
\hline
\end{tabular}

the dentary bone (Figure 2). The specimens have 42-43 scales in the lateral line, seven rows of scales between the lateral line and the origin of the dorsal fin, six rows of scales between the lateral line and the origin of the pelvic fin, and 16 rows of scales around the caudal peduncle. These characteristics, together with the morphometry of the specimens, are fully consistent with the descriptions of M. macrocephalus published Garavello and Britski (1988) and Britski et al. (1999), and leave no doubt with regard to the identity of the taxon.

Four COI sequences were obtained, one from the specimen collected from the Itapecuru River, and three from the specimens obtained from the basin of the Mearim River. Comparisons with the sequences available in the BOLDSystems database confirmed the morphological identification of the specimens. The $\mathrm{COI}$ sequences obtained from the specimens collected in the present study were more than $99 \%$ similar to that of $M$. macrocephalus from the basin of the Paraná River (Table 2). This value is well within the $2 \%$ threshold for the identification of fish species by DNA barcoding (Ward et al., 2009; April et al., 2011; Carvalho et al., 2011; Mabragaña et al., 2011; Castro Paz et al., 2014).

\section{Discussion}

No records of $M$. macrocephalus species were obtained during previous studies in the Itapecuru and Mearim rivers (Soares, 2005; Barros et al., 2011; Fraga et al., 2012; Nascimento et al., 2016; Abreu et al., 2019). It seems likely that the species was exhaust accidentally during the rainy season, when the tanks of local fish farms overflow and become connected with the tributaries of the two basins.
The species M. macrocephalus is used in fish pisciculture, larger and has economic importance for fishing in some regions, in particular in the Pantanal Mato-grossense (Navarro et al., 2007). M. macrocephalus is well-suited to fish pisciculture, which has led to its accidental introduction into a number of different Brazilian river basins (Godinho and Godinho, 2003; Barbosa and Soares, 2009; Vieira, 2010).

It is interesting to note that $M$. macrocephalus has not been recorded in recent surveys of other, nearby basins, in the Brazilian Northeast, including the Munim and Parnaíba in Maranhão/Piauí (Matavelli et al., 2015), the Parnaíba in Maranhão/Piauí (Ramos et al., 2014), and the São Francisco, in Bahia (Carvalho et al., 2011).

The records of $M$. macrocephalus presented here represent an important extension of the known distribution of the species, whose occurrence is now confirmed in the Itapecuru and Mearim rivers of Maranhão, in the Brazilian Northeast. It is nevertheless premature to confirm that M. macrocephalus has established viable populations in these rivers, and what effects its presence may have on the resident species. However, the introduction or transfer of exotic fish species into a river basin, whether intentional or otherwise, almost always has negative implications for the resident native species (Pelicice et al., 2014), and any invasion of this type requires carefully-planned management strategies to guarantee the long-term integrity of the local biota.

\section{Conclusion}

The combined analysis of morphological and molecular analysis confirmed the occurrence of $M$. macrocephalus in the Itapecuru and Mearim Rivers, state of Maranhão. 
This substantially amplifies the known distribution of this species to the Brazilian Northeast.

\section{Acknowledgements}

We are grateful to the Maranhão State Foundation for Technology and Scientific Research (FAPEMA). We would also like to thank CNPq for conceding a research stipend tp JLOB (302872/2018-3).

\section{References}

ABREU, J.M.S., CRAIG, J.M., ALBERT, J.S. and PIORSKI, N.M., 2019. Historical biogeography of fishes from coastal basins of Maranhão State, northeastern Brazil. Neotropical Ichthyology, vol. 17, no. 2, pp. e180156. http://dx.doi.org/10.1590/19820224-20180156.

ALCÂNTARA, E.H., 2004. Caracterização da bacia hidrográfica do Rio Itapecuru, Maranhão. Caminhos de Geografia, vol. 7, no. 11, pp. 97-113.

ALVES, C.B.M., VIEIRA, F., MAGALHÃES, A.L.B. and BRITO, M.F.G., 2007. Impacts of nonnative fish species in Minas Gerais, Brazil: present situation and prospects. In: T.M. BERT, ed. Ecological and genetic implications of aquaculture activities. Dordrecht: Springer, pp. 291-314. http://dx.doi.org/10.1007/978-1-4020-6148-6_16.

APRIL, J., MAYDEN, R.L., HANNER, R.H. and BERNATCHEZ, L., 2011. Genetic calibration of species diversity among North America's freshwater fishes. Proceedings of the National Academy of Sciences of the United States of America, vol. 108, no. 26, pp. 10602-10607. http://dx.doi.org/10.1073/pnas.1016437108. PMid:21670289.

BARBOSA, J.M. and SOARES, E.C., 2009. Perfil da ictiofauna da bacia do São Francisco: estudo preliminar. Revista Brasileira de Engenharia de Pesca, vol. 4, no. 1. http://dx.doi.org/10.18817/ repesca.v4il.140.

BARCODE OF LIFE DATA SYSTEMS - BOLD [online], 2020 [viewed 17 May 2020]. Available from: http://www.boldsystems.org

BARROS, M.C., FRAGA, E.C. and BIRINDELLI, J.L.O., 2011. Fishes from the Itapecuru river basin, state of Maranhão, northeast Brazil. Brazilian Journal of Biology = Revista Brasileira de Biologia, vol. 71, no. 2, pp. 375-380. http://dx.doi.org/10.1590/S151969842011000300006. PMid:21755154.

BERTACO, V.A., FERRER, J., CARVALHO, F.R. and MALABARBA, L.R., 2016. Inventory of the freshwater fishes from a densely collected area in South America: a case study of the current knowledge of Neotropical fish diversity.Zootaxa, vol. 4138, no. 3, pp. 401-440. http://dx.doi.org/10.11646/zootaxa.4138.3.1. PMid:27470773.

BIRINDELLI, J.L.O., BRITSKI, H.A. and GARAVELLO, J.C., 2013. Two new species of Leporinus Agassiz (Characiformes: Anostomidae) from eastern basins of Brazil, and redescription of L. melanopleura Günther. Neotropical Ichthyology, vol. 11, no. 1, pp. 9-23. http:// dx.doi.org/10.1590/S1679-62252013000100002.

BRITSKI, H.A. and GARAVELLO, J.C., 1978. Sobre Leporinus octofasciatus Steindachner da bacia do Paraná (Pisces, Anostomidae). Papéis Avulsos de Zoologia, vol. 31, pp. 237-250. http://dx.doi.org/10.1590/S1679-62252013000100003.

BRITSKI, H.A., SILIMON, K.Z.S. and LOPES, B.S., 1999. Peixes do Pantanal: manual de identificação. Corumbá: Embrapa-SPI, Brasília /Embrapa-CPAP, 184 pp.

BURNS, M.D., CHATFIELD, M., BIRINDELLI, J.L.O. and SIDLAUSKAS, B.L., 2017. Systematic assessment of the Leporinus desmotes species complex, with a description of two new species. Neotropical
Ichthyology, vol. 15, no. 2. http://dx.doi.org/10.1590/19820224-20160166.

CARVALHO, D.C., OLIVEIRA, D.A.A., POMPEU, O.S., LEAL, C.G., OLIVEIRA, C. and HANNER, R., 2011. Deep barcode divergence in Brazilian fresh water fishes: the case of the São Francisco river basin. Mitochondrial DNA, vol. 22, suppl. 1, pp. 80-86. http:// dx.doi.org/10.3109/19401736.2011.588214. PMid:21699373.

CASTRO PAZ, F.P., BATISTA, J.D.S. and PORTO, J.I.R., 2014. DNA barcodes of rosy tetras andallied species (Characiformes: Characidae: Hyphessobrycon) from the Brazilian Amazon basin. PLoS One, vol. 9, no. 5, pp. 1-8. http://dx.doi.org/10.1371/ journal.pone.0098603.

DAGOSTA, F.C.P. and PINNA, M.C.C., 2019. The fishes of the Amazon: distribution and biogeographical patterns, with a comprehensive list of species. Bulletin of the American Museum of Natural History, vol. 431, no. 1, pp. 1-163. http://dx.doi. org/10.1206/0003-0090.431.1.1.

FRAGA, E.C., BIRINDELLI, J.L.O., AZEVEDO, C.A.S. and BARROS, M.C., 2012. A Ictiofauna da Área de Proteção Ambiental Municipal do Inhamum, Caxias/MA. In: M.C. BARROS, ed. Biodiversidade na Área de Proteção Ambiental Municipal do Inhamum. São Luís: UEMA, pp. 107-116.

FRICKE, R., ESCHMEYER, W.N. and FONG, J.D., 2020 [viewed 17 May 2020]. Eschmeyer's catalog of fishes: species by family/subfamily [online]. Available from: http://researcharchive.calacademy.org/ research/ichthyology/catalog/SpeciesByFamily.asp

FRICKE, S.N., 2019. Introduction: indigenous futurisms in the hyperpresent now. World Art, vol. 9, no. 2, pp. 107-121. http:// dx.doi.org/10.1080/21500894.2019.1627674.

GARAVELLO, J.C. and BRITSKI, H.A. 2003. Family Anostomidae. In: R. E. REIS, S. O. KULLANDER and C. J. FERRARIS JÚNIOR, eds. Check List of the Freshwater Fishes of South and Central America. Porto Alegre: EDIPUCRS, pp. 71-84.

GARAVELLO, J.C. and BRITSKI, H.A., 1988. Leporinus macrocephalus sp. da bacia do rio Paraguai (Ostariophysi, Anostomidae). Naturalia, vol. 13, pp. 67-74.

GODINHO, H.P. and GODINHO, A.L., 2003. Águas, peixes e pescadores do São Francisco das Minas Gerais. Belo Horizonte: PUC Minas, pp. 133-148.

GOMES, L.C., PESSALI, T.C., SALES, N.G., POMPEU, P.S. and CARVALHO, D.C., 2015. Integrative Taxonomy detects cryptic and overlooked fish species in a Neotropical river basin. Genetica, vol. 143, no. 5, pp. 581-588. http://dx.doi.org/10.1007/s10709-015-9856-z. PMid:26142058.

GRAÇA, W.J. and PAVANELLI, C.S., 2007. Peixes da planície de inundação do Rio Paraná. Maringá: EDUEM, 241 p.

HALL, T.A., 1999. BioEdit: a user-friendly biological sequence alignment editor and analysis program for Windows 95/98/ NT. Nucleic Acids Symposium Series, vol. 41, pp. 95-98.

INSTITUTO BRASILEIRO DE GEOGRAFIA E ESTATÍSTICA - IBGE, 2014. Produção da pecuária municipal. Rio de Janeiro: IBGE.

LANGEANI, F., CASTRO, R.M.C., OYAKAWA, O.T., SHIBATTA, O.A., PAVANELLI, C.S. and CASATTI, L., 2007. Diversidade da ictiofauna do Alto Rio Paraná: composição atual e perspectivas futuras. Biota Neotropica, vol. 7, no. 3, pp. 1-18. http://dx.doi.org/10.1590/ S1676-06032007000300020.

MABRAGAÑA, E., DÍAZ DE ASTARLOA, J.M., HANNER, R., ZHANG, J. and GONZÁLEZ CASTRO, M., 2011. DNA Barcoding Identifies Argentine Fishes from Marine and Brackish Waters. PLoS One, vol. 6, no. 12, pp. e28655. http://dx.doi.org/10.1371/journal. pone.0028655. PMid:22174860. 
MARANHÃO. Governo do Estado do Maranhão, 2011. Bacias hidrográficas: subsídios para o planejamento e a gestão territorial. São Luís: Universidade Estadual do Maranhão/ Núcleo Geoambiental.

MATAVELLI, R., CAMPOS, A.M., VALE, J., PIORSKI, N.M. and POMPEU, P.S., 2015. Ichthyofauna sampled with tadpoles in northeastern Maranhão state, Brazil. Check List, vol. 11, no. 1, pp. 1550. http:// dx.doi.org/10.15560/11.1.1550.

NASCIMENTO, M.H.S., ALMEIDA, M.S., VEIRA, M.N.S., LIMEIRA FILHO, D., LIMA, R.C., BARROS, M.C. and FRAGA, E.C., 2016. DNA barcoding reveals high levels of genetic diversity in the fishes of the Itapecuru Basin in Maranhão, Brazil. Genetics and Molecular Research, vol. 15, no. 3, pp. 1-11. http://dx.doi org/10.4238/gmr.15038476. PMid:27706636.

NAVARRO, R.D., LANNA, E.A.T., DONZELE, J.L., MATTA, S.L.P. and SOUZA, M.A., 2007. Níveis de energia digestível da dieta sobre o desempenho de piauçu (Leporinus Macrocephalus) em fase pós-larval. Acta Scientiarum, vol. 29, no. 1, pp. 109-114. http:// dx.doi.org/10.4025/actascianimsci.v29i1.266.

NAVARRO, R.D., MATTA, S.L.P. and LANNA, E.A.T., 2006. Níveis de energia digestível na dieta do piauçu (Leporinus macrocephalus) no desenvolvimento testicular em estágio pós-larval.Zootecnia Tropical, vol. 24, no. 2, pp. 153-163.

PELICICE, F.M., VITULE, J.R.S., LIMA JUNIOR, D.P., ORSI, M.L. and AGOSTINHO, A.A., 2014. A serious new threat to brazilian freshwater ecosystems: the naturalization of nonnative fish by decree. Conservation Letters, vol. 7, no. 1, pp. 55-60. http:// dx.doi.org/10.1111/conl.12029.

PERUCA, A.P.S., TEIXEIRA, I. and BENNEMANN, S.T., 2000. Frugivoria em jovens de três espécies de peixe do gênero Leporinus. In: Anais do XXIII Congresso Brasileiro de Zoologia, 2000, Cuiabá. Cuiabá: Sociedade Brasileira de Zoologia, 381 p.

RAMIREZ, J.L., BIRINDELLI, J.L.O. and GALETTI JUNIOR, P.M., 2017. A new genus of Anostomidae (Ostariophysi: Characiformes): diversity, phylogeny and biogeography based on cytogenetic, molecular and morphological data. Molecular Phylogenetics and Evolution, vol. 107, pp. 308-323. http://dx.doi.org/10.1016/j. ympev.2016.11.012. PMid:27894994.
RAMOS, T.P.A., RAMOS, R.T.C. and RAMOS, S.A.Q.A., 2014. Ichthyofauna of the Parnaíba river basin, northeastern Brazil. Biota Neotropica, vol. 14, no. 1, pp. e20130039. http://dx.doi. org/10.1590/S1676-06020140039.

RATNASINGHAM, S. and HEBERT, P.D.N., 2007. BOLD: the Barcode of Life Data System (www.barcodinglife.org). Molecular Ecology Notes, vol. 7, no. 3, pp. 355-364. http://dx.doi.org/10.1111/j.14718286.2007.01678.x. PMid:18784790.

SANGER, F., NICKLEN, S. and COULSON, A.R., 1977. DNA sequencing with chain-terminating inhibitors. Proceedings of the National Academy of Sciences of the United States of America, vol. 74, no. 12, pp. 5463-5467. http://dx.doi.org/10.1073/pnas.74.12.5463. PMid:271968.

SOARES, C.M., HAYASHI, C., FURUYA, V.R.B., FURUYA, W.M. and GALDIOLI, E.M., 2000. Substituição parcial e total da proteína do farelo de soja pela proteína do farelo de canola na alimentação de alevinos de Piavuçu (Leporinus macrocephalus). Revista Brasileira de Zootecnia, vol. 29, no. 1, pp. 15-22. http://dx.doi. org/10.1590/S1516-35982000000100003.

SOARES, E.C., 2005. Peixes do Mearim. 10. ed. São Luis: Editor Instituto Geia, vol. 10, 143 p.

UNIVERSIDADE ESTADUAL DO MARANHÃO - UEMA. Centro de Ciências Agrárias. Núcleo Geoambiental, 2016. Bacias hidrográficas e climatologia no Maranhão. São Luís: UEMA, 165 p.

VIEIRA, F., 2010. Distribuição, impactos ambientais e conservação da fauna de peixes da bacia do rio Doce. MG.Biota, vol. 2, pp. 5-22.

WARD, R.D., HANNER, R. and HEBERT, P.D.N., 2009. The campaign to DNA barcode all fishes. Journal of Fish Biology, vol. 74, no. 2, pp. 329-356. http://dx.doi.org/10.1111/j.1095-8649.2008.02080.x. PMid:20735564.

WARD, R.D., ZEMLAK, T.S., INNES, B.H., LAST, P.R. and HEBERT, P.D.N., 2005. DNA barcoding Australia's fish species. Philosophical Transactions of the Royal Society of London. Series B, Biological Sciences, vol. 360, no. 1462, pp. 1847-1857. http://dx.doi. org/10.1098/rstb.2005.1716. PMid:16214743.

ZEINAD, A.K. and PRADO, R.A., 2012. Peixes fluviais do Brasil espécies esportivas. São Paulo: Pescaventura, 360 p. 